\title{
MERGER AND DIVISION NULLITY IN THE ROMANIAN LEGAL SYSTEM
}

\author{
F. Bejan \\ Felicia Bejan \\ The Bucharest University of Economic Studies, Department of Law \\ *Correspondence: Felicia Bejan, Faculty of Political Science, 24 Sfântul Ştefan St. Bucharest, \\ Romania \\ E-mail: felicia.bejan@fspub.unibuc.ro
}

\begin{abstract}
As a consequence of the transposition of European Directives regarding the merger, division, and cross-border mergers, the Romanian legal system established a special legal framework with regard to the sanction of nullity for such juridical acts. The peculiarities of internal and cross-border reorganisation operations and the imperative of protecting the interests of third parties, associates, and the companies involved led to the creation of a derogatory legal system on the matter. An analysis of both theoretical and practical perspectives of the subject matter may result in a useful instrument for the application of incidental legal norms, or every time restructuring juridical acts contravene the legal norms.
\end{abstract}

Key terms: nullity, merger, division, judicial character, nullity remedy.

\section{Introduction}

Generically, mergers and divisions are juridical acts concluded with the agreement of the participating legal persons and which, for their valid coming to being, need to fulfil conditions regarding the capacity, consent, object, cause and form regulated by legal norms.

Contrary to most juridical acts, mergers and divisions are concluded under particular form and substance conditions imposed by law, justified by the complexity and effects of such acts in relation to the very existence of the legal entities involved.

Given that the valid concluding of a juridical act requires more conditions to be accomplished, leading therefore to the existence of a bigger number of nullity causes, the importance of the respect for the rule of law in every moment and for every part of the merger or division procedure becomes obvious.

\section{The legal background}

The merger and division nullity is regulated by the Law 31/1991 in article 251. As it results from the legal dispositions, the merger and division nullity sanction concerns the merger or division process producing effects, according to the law article 249. Therefore, the accuracy and legality of different specific acts and formalities undertaken during the merger or division procedure will be able to make the object of a legal action only after the merger or division juridical act begins to produce legal effects.

The merger and division legal regime derogates from the common law regime concerning the nullity of the juridical act, according to the stipulations of the European directives with regards to mergers and divisions. In the preliminaries of the joint-stock companies Merger Directive ${ }^{\circ}$ III, respectively of the Division Directive $n^{\circ}$ IV, it is shown that one of the objectives to be achieved by the Member States consists in the broadening of the guaranties provided to shareholders or third parties with regard to mergers and divisions. Thenceforth, in the justification part of the European legislative acts, it is mentioned that "in order to ensure the legal certainty in those reports between companies involved in mergers or 
divisions, in those between the concerned companies and third parties, and in those legal relations involving the shareholders, the nullity causes has to be restricted by providing the possibility of rectifying an irregularity every time it is possible and by reducing the legal period of time for invoking the nullity" ${ }^{\prime 2}$. As a result of the transposition into national law of the european directives, the Romanian legislator limited the number of nullity causes and the period of time in which it can be invocated, protects the third parties against the retroactivity of the nullity effects concerning those, and prefers the solution of rectifying illegal situations to sanctioning mergers and divisions by nullity.

\section{The judicial character of the merger and division nullity}

The Law 31/1990 regulates through imperative norms the judicial character of the nullity specific to mergers and divisions. Therefore, according to article 251 , paragraph 1 , which transposes into national law the article 22, paragraph 1, letter a) of the Merger Directive $\mathrm{n}^{\circ}$ III and of the article 19, paragraph 1, letter a) Division Directive $\mathrm{n}^{\circ}$ IV regarding joint-stock companies, the nullity specific to mergers or divisions can be decided only by court order ${ }^{29}$.

According to the interpretation of the law, it follows that this disposal is likely to forbid any other appreciation method of the null or voidable character of the merger or division juridical act. In presence of such a conclusion, the question arising is whether the merger or division nullity can be covered by expressed or tacit confirmation.

In our belief, contrary to common law, in mergers or divisions, explicit or tacit confirmation of absolute or relative nullity is unacceptable. In other words, people entitled to invoking the nullity of the merger or division juridical act, cannot renounce to this right, with the aim of covering the nullity, even though such a measure would suit their interests. To argue otherwise would mean to agree that every person interested to invoke the nullity can implicitly decide that the merger or division act is either null, or voidable, as appropriate ${ }^{30}$. Yet, only the courts of law are competent to rule.

The European merger and division Directives give member states the possibility to derogate from the juridical character of the merger or division nullity. In this respect, the legislation of a Member State can regulate the pronouncement of nullity with regards to mergers or divisions by the administrative authorities, provided that the decision could be contested in court. The administrative authorities, in the exercise of their competencies, will make a decision by applying the rules specifically stipulated with regards to the pronouncement of the merger or division nullity by the judicial authorities.

Moreover, the European legislator offers the possibility of the nullity pronouncement for mergers or divisions as a result of a monitoring process, other than the judicial or administrative preventive control, in those member states where the legislation in force provides for such a possibility.

The Romanian legislator opted for a regulatory framework insuring a rigorous application of the nullity sanction, as well as the legality certainty of the merger process.

\footnotetext{
${ }^{28}$ Preliminaries - The joint-stock companies Merger Directive $n^{\circ}$ III and Division Directive $n^{\circ}$ IV.

29 According to European regulations, Member States can state in their national normative acts that the verification of the merger or division legality has to be made either by the judicial authorities, or the administrative authorities. In case if in any of the Member states, the regulations regarding the control of the merger or division legality are incomplete, the legal acts necessary to mergers or divisions have to be drawn up and certified in compliance with the adequate legal form.

${ }^{30}$ The confirmation of a null act doesn't have to be confused with the rectification of a null act. The rectification of the legal act for mergers and divisions is acceptable and produces effects from the date of its conclusion, contrary to the confirmation of a null act which produces effects retroactively.
} 


\section{The prescription term for the merger or division nullity action}

The action for annulment or declaration of nullity with regards to mergers or divisions can be exercised within six months from the moment when the merger or the division process became effective, according to article 249.

Both the absolute nullity and the relative nullity with regards to mergers and divisions can be invoked within six months, starting with the moment when these juridical acts begin to produce effects, as follows:

- from the date of registration in the commercial registry of the new company, in case of merger whereby all participating companies cease to exist and a new one is formed;

- from the date established by the parties, by their agreement, as the moment from which the merger or the division will produce effects;

- from the date of registration in the commercial registry of the last company newly created, in case of division by transmission of the assets belonging to the company under division towards many companies taking such being;

- from the date when the decision of the most recent shareholders meeting approving the operation was registered in the case of merger by absorption and of division by transmission of the assets of the company under division towards many existing companies.

The six-month term is a special extinctive prescription term, liable for suspension, and interruption, and to which apply the provisions regarding the possibility of reinstatement.

Being a term expressed in months, the term will expire on the day corresponding to the day it started to run, of the sixth month ${ }^{31}$. Actions introduced once the 6-month term will have expired will be rejected as belated ${ }^{32}$.

The question arising is whether the 6-month term in which the action for declaration of merger or division nullity can be introduced, applies only to relative nullity or, as an exception to the rule of imprescriptibility of absolute nullity, can be applied to this one as well. Two kinds of approaches and solutions to this issue are possible.

As a first hypothesis it can be argued that the term can apply only with regards to relative nullity given that the prescription term applies, from a simple juridical logic perspective, only to actions which are prescriptible. Given that only to relative nullity it is likely to be applied a prescription term, the conclusion would be that absolute nullity does not fall within the application field of this term.

According to a second position, with which we agree, we cannot make distinctions that are not provided by the legal norm, a rule consecrated by the Latin adagio ubi lex non distinquit, nec nos distinquere debemus. This means that there is only one solution to the legal issue we analysed, meaning that the 6-month term in which the action for declaration of merger or division nullity can be initiated applies, by exception, both to relative nullity and absolute nullity ${ }^{33}$.

\footnotetext{
${ }^{31}$ If the last month doesn't have a corresponding day, the term is considered as being expired in the last day of that month.

${ }^{32}$ In an action for annulment of a merger by creating a new company, the Court accepted the exception of late introduction of the action for annulment as founded because the merger begins to produce effects from the date when the last decision of the general shareholders' meeting approving the process was taken, and since then have passed more than 6 months, The Court of Appeal Bucharest, The 4th Commercial Section, case $n^{\circ}$ 178, April 10 2009.

${ }^{33}$ In the same way, the law 137 from the 28th of March 2002 concerning the measures to be taken for the acceleration of the privatization process published in the Official Journal of the 28th of March 2002, in chapter VI, and called Special provisions concerning mergers, divisions, dissolutions and liquidations of joint-stock companies submitted to the privatization process, article 32, paragraph 2, provides a special 5-day prescription term with regard to the merger and division nullity, without making any difference between absolute and relative nullity.
} 


\section{The nullity remedy}

To ensure a better protection of the interests of the companies participating in mergers or divisions, the article 251, paragraph 3 of the Law 31/1990 regulates the remedy of those irregularities likely to give shape to an action for annulment or declaration of nullity.

The court of law in charge with an action for nullity has to provide to the involved companies a term in which the thereby invoked irregularities could be rectified, provided that, based on the adduced evidence, it appreciates the given situation as likely to be rectified. The accomplishment process of remediation determines the dismissal of the action as unfounded and illegal. In practice, the rectification of those rules conducive to a merger or division annulment can be achieved by the parties before addressing the Court, situation when such an action wouldn't be appropriate anymore and therefore will be rejected by the Court.

In our view, the article 251, paragraph 3 expressly regulates the rectification of the juridical act regarding mergers and divisions. The rectified juridical act represents a new juridical act producing affects from the moment of its conclusion. Because every rectification of acts concerning mergers and divisions determines a change of the merger or division juridical act, it will become effective in the moment of its registration, in compliance with the modifications it has known, as it is shown in article 249 of the law.

\section{The causes determining the merger or division}

The causes leading to the exercise of the action for annulment or declaration of nullity with regards to mergers or divisions are express prescribed by the law.

Therefore, according to article 251, paragraph 2, mergers and divisions can be declared null only for the next two reasons:

- because of breaking the legal disposals regarding the obligation of the merger or division judicial control, and

- because of the absolute or relative nullity of one of the decisions taken by the general assembly having voted for the merger or division project ${ }^{34}$

a) The first nullity case refers to the breaking of legal dispositions regarding the judicial control on mergers and divisions.

According to article 37, paragraph 1, the acts or facts that, in compliance with the law, are registered to the registry of commerce, are submitted to the legality control which is exercised by the institution of Justice through a delegated judge.

To apply this legal disposition, all the involved companies are obliged to submit the merger or division project, signed by their representatives, to the registry of commerce were they are registered. Together with this project, the company or the companies ceasing to exist have to submit a declaration regarding the way in which the passive doesn't exist anymore.

The delegated judge to the registry of commerce verifies if the project is prepared according to the legal conditions and approves it for the further publication in the Official Journal.

If the merger or division project is modified after its approval and publication, the project in its new form is going to be submitted to a new control of legality and respect of the advertising formalities ${ }^{35}$.

\footnotetext{
${ }^{34}$ According to article 22, letter b) of the joint-stock companies Merger Directive $\mathrm{n}^{\mathrm{o}}$ III and Division Directive $\mathrm{n}^{\mathrm{o}}$ IV, mergers and divisions can be declared null only if their legality was not submitted to a preventive juridical or administrative control, if they hadn't been concluded or certified in due legal form or if it is shown that the decision of the general assembly is null or likely to be cancelled according to national law.

${ }^{35}$ It was decided in a Court rule that the modification of the merger plan does not automatically imply the deletion of the stipulations made within the merger project. These stipulations are made so that those interested may gain knowledge of the merger intent and gain the ability to manifest their agreement or opposition to the merger project. By the subsequent approving or rejecting of the merger, or by approving of it with amendments, the initial stipulations made on the basis of the project cease to produce effects, the only remaining part to produce effects being the merger in itself. As a consequence, the action for annulment was rejected, motivated,
} 
As a result of the modification known by the merger or division project, the date from which is calculated the term when the social creditors can bring forth an objection, respectively the date up to which they can call a general shareholders' meeting that will decide the approval of the merger or division process, will chance accordingly.

In practice, in our national legal system, the possibility to register mergers or divisions without a prior submission to a legal control is difficult to conceive of, particularly given the double control such acts are subjected to, and the registration of the acts enabling the effective existence of mergers and divisions is not possible without their prior verification. This kind of nullity is relevant within the European law systems where the juridical acts specific to companies are not submitted to a rigorously regulated control of the legal or administrative authorities. It concerns namely those legal systems which either don't require a judicial or administrative control of the merger or division legality, or, although such a control is regulated, it does not refer to each of the legal acts necessary to close the operation and, if the case, the merger or division contract is neither concluded, nor certified in a proper legal form $^{36}$.

b) The second case of merger or division nullity concerns the situation when the decision of one of the general assembly having voted the merger or the division project is null or prone to annulment. Therefore, the merger or division nullity is in this case the effect of the nullity of the general assemblies.

The merger or division nullity can be required not only because the validity general conditions that every decision of the general shareholders meeting were broken, but also because the special legality conditions required by law have not been respected.

Not adhering to the general rules regarding the call to assembly of the general shareholders meeting, of those rules concerning the shareholders' representation within the general assembly, of those norms specific to the general assembly taking place, as well as the taking decisions without respecting the general shareholders' meeting agenda by the general shareholders meeting are only some of the reasons able to determine the merger or division nullity.

As such, in one of the jurisprudence cases dealing with this kind of situations, it was decided that the decision of the general shareholders' meeting regarding the merger process has to accomplish the general validity conditions. Thus, the decision of the general shareholders' meeting is likely to be cancelled if the administrator having contrary interests participated to the decision making. Such a situation appears when the administrator is the main shareholder and holds the position of administrator with two societies holding the majority of shares both to the incorporating company and the incorporated one ${ }^{37}$.

In another case, it was decided that the action submitted by the accuser for the declaration of absolute nullity of the decision taken by the general shareholders' meeting and of all the acts concluded for its convening and performance, as well as for the declaration of absolute nullity of the division project and the additional document made under it, is founded. To make such a decision, the instance ascertained that the mandate of the administrators' and the defendant's auditors mandate has expired, and the fact that by the moment of the general shareholders' meeting decision, the defendant didn't have statutory bodies represent a nullity

among others, by the failure to fulfil the formalities to annul the stipulations made on the basis of the initial merger project. The Craiova Court of Appeal, the Commercial Section, case $n^{o} .23$ of 19 January 2005, op. cit., pp 568-569.

${ }^{36}$ According to the E.U. Directives in the field, the notary or the competent authority to prepare and certify the merger or division documents in an adequate legal form, has to verify and testify the existence and the legality of the acts and formalities imposed to the company on whose behalf they exist, and of the merger or division project.

37 The High Court of Cassation and Justice, the Commercial Section, decision no. 2287 of 1 April 2005 op. cit, pp. 579--580. 
cause in what it is concerned. In the same case, the court stated that the evidence consisting of expert tests were wrongly rejected based on the administration of the evidence by the delegated judge to the registry of commerce. The court showed that the procedure taking place at the registry of commerce has a non-contencious nature, so that on the occurrence of a conflict, in contradictory conditions, the administration of the evidence consisting of a new expert test, the court has to approve it for a fair resolution of the case. Otherwise, it is not possible to examine the merits of the defendant's claims, namely as the evidence was carried out within a non-contencious procedure, at the request of the other party ${ }^{38}$.

Finally, in another case, the court decided that the decision of the general shareholders' meeting having decided the division of the company was illegal, given that when invoking the complete text of the proposal regarding the modification of the constitutive act didn't appear, and the agenda didn't include all the aspects with regard to which the general shareholders' meeting adopted decisions ${ }^{39}$.

On the other hand, infringing the special legal dispositions which regulate mergers or divisions can represent as many causes of nullity as there are dispositions. Therefore, the lack of, the illegality, or the groundlessness of any of the mandatory pieces of information in the merger or division project, the irregularities characteristic to the financial situations created to register mergers or divisions, the infringing of the rules concerning the quorum and the majority requirements provided by law to make decisions, the violation of the obligation regarding the making available of documents to shareholders, the violation of the procedural requirements regulating mergers or divisions, can be invoked within the action for annulment or the action of declaration of absolute nullity of the merger or division juridical acts.

The move to declare nullity with regard to mergers or divisions can be exercised by the shareholders or the associates of the joint-stock companies participating to the merger or division, in case of relative nullity, and by every interested physical or legal person, as well as by the state through its representatives, in case of absolute nullity.

If the action is accepted, the final decision of declaring the nullity of the merger or division will be transmitted ex officio by the court to the officials of the registry of commerce where the companies involved in the merger or division process have registered. The registry of commerce will order the registration of the decision and its transmission for publishing to the Official Journal.

It can make the object of an analysis whether, apart these specific nullity causes, the annulment of the merger or division process can be decided as well because of vices of consent, the breaking of legal dispositions concerning the legal capacity, the lack of validity either of the object or the cause of the juridical act.

Although the procedure formalism is desired to be a guarantee for the legality of the merger or division juridical act, it is generally known that the powerful partners abusively dominate, sometimes in an invisible way, their partners who ultimately depend on them, which raises questions regarding the latter's capacity to freely express their consent. From a similar perspective, it can be analysed whether mergers or divisions have a valid or invalid cause. Of course, the cause is a validity element of the convention that is very hard to prove, given its nature. Nevertheless, we have to admit that, beyond the merger or division stated objective, there is a high probability that the objective followed by the participants when they conclude the merger or division legal act be contrary to the law, good morals and of public order. The issue here seems to be more of a theoretical one, rather than practical, and its formulation might have a role of prevention of the shareholders or of associates regarding the

\footnotetext{
${ }^{38}$ The High Court of Cassation and Justice, the Commercial Section, decision no. 1942 of $21^{\text {st }}$ of March 2005, op.cit., pp. 584-586.

${ }^{39}$ Ibidem.
} 
appropriate approach to be used when analysing mergers or divisions, so that preventive measures leading to the protection of personal interests can be taken.

\section{The effects of the merger or division nullity}

In principle, similarly to the common law nullity, the merger or division nullity has retroactive effects, the joint-stock companies returning to the prior condition, while the acts subsequent to the null act are cancelled as a consequence of the initial act being cancelled.

By derogation from the common law principles, the merger or division nullity is not retroactive with regards to the obligations born from the juridical reports closed after the operation, but prior to its dissolution. Briefly, we can say that the nullity has no influence on those given obligations which are required to be honoured.

According to article 251, paragraph 6 of the Law 31/1990, the final decision declaring the merger or division nullity doesn't affect by itself the validity of the obligations in charge of or for the benefit of the absorbing companies or the beneficiary companies, assumed once the merger or the division have become effective, according to article 249 , and before the nullity decision be published. These obligations are jointly assumed by the companies involved in the merger or division process.

If a merger nullity is decided, the participating companies to the merger are jointly responsible for the obligations of the absorbing company, resulting only once the merger became effective, but before the publication of the nullity decision.

By effect of the law, absorbed and merging companies engage their responsibility together with the absorbing and the newly created companies for obligations in charge of the last ones, even though they cease to exist in the moment when the new juridical relationships generating these obligations were concluded.

In case of a division nullity, the law establishes a limited responsibility for the reorganised company with regard to the obligations in charge of the beneficiary companies.

Therefore, as a result of a nullity decision in the case of a division, the responsibility is shared between the division companies and the beneficiary companies as follows:

- each beneficiary company holds responsibility for its own obligations, engaged after the division having become effective, but before the publication of the nullity decision,

while

- the company under division holds responsibility for these obligations within the limits of the percentage of net shares that have been transferred to the beneficiary company on whose account were born the given obligations.

Mergers and divisions are complex processes that engage important resources of the companies. The question arising is who holds responsibility for the situation when, at the end of an important effort, it is decided that nullity is decided. De lege lata, the joint-stock company law contains some dispositions regarding the administrators' responsibility for the legality of the merger or division process. In our view, given that administrators act under the legitimacy of a mandate they were given by the initiators of the merger or division, de lege ferenda, the responsibility regulation applies to all the people involved in the merger or division process.

\section{The nullity of the cross-border merger}

The nullity of the cross-border merger is governed within the Romanian legal system by the provisions of the article $251^{19}$ of Law $31 / 1190$ on trade companies. At a first view, we could consider that nullity of the cross-border merger is characterized, generally speaking, by a legal regime similar to that characterizing the national merger nullity, the only difference consisting of a more detailed regulation of the latter one. As in the case of the national merger nullity, the law consecrates the judicial character of the cross-border merger, the possibility to rectify the nullity and the obligation of the competent instance to transmit ex officio the final decision of the nullity to the officials from the register of commerce where the companies 
involved in the merger process have their social office. We could say that, despite a more concise regulation, for those aspects which haven't been yet regulated by a special law, is applying the common law in the field.

Yet, the entire reasoning we built is invalidated by a careful reading of paragraph 2, of article $251^{19}$ stating that: "The merger nullity cannot apply after the date when the merger has begun to produce effects, the date being established according to article $251^{15}$ paragraph 2 ". The law makes no distinction between absolute nullity and relative nullity.

Therefore we have a certainty that makes useless any attempt to analyse the institution of nullity for cross-border merger, simply because it doesn't exist. In a radical way, the Directive 2005/56/ECC and the Law 31/1990 exclude the nullity from the sanctions applicable to the cross-border merger. Those authors interested in the field of intracommunity mergers brought arguments for this surprising deregulation, eventually qualifying its rigorous character as a safety measure necessary to all those involved, given the crossborder character of this process.

As to what we are concerned, every time a legislative measure appears to be adopted with certain restrictions, we believe that the competing protected interests have to be considered as well. In this case, the interests and the effects of an action for nullity have to be compared with the interests and the effects of the security of the process. We consider that a comparative quantitative analysis and a qualitative analysis of these ones, together with the regulation regarding the merger double control mechanism tip the balance for the solution of forbidding the nullity.

Contrary to the cross-border nullity interdiction, we consider that, in an erroneous way, the Romanian legislator adopted rules regarding the judicial character of nullity, the rectification of nullity, and the communication of the decision to accept the nullity. Yet, regulating legal aspects of an institution which doesn't exist is lacking any logic, namely the legal one. Therefore, de lege ferenda, the abrogation of paragraphs 1,3 , and 4 of article $251^{15}$ is mandatory as they don't have an object of regulation.

\section{Conclusions}

The need for a derogating legal regime with regard to the cross-border restructuring processes appeared as a result of the need to guarantee the juridical acts affected by these mechanisms. The control of the valid conclusion of merger and division legal acts is strictly regulated under the aspect of competency, of the prescription term, of the rectification, of the nullity causes and effects. Moreover, in what concerns the merger of companies in member states, the legal provisions are radical. Due to the cross-border character of the process, and because of the risks to which would be exposed the participating companies, associates, employees, and creditors by promoting of the action for nullity, the legislator preferred to deregulate it. Mergers, divisions, and cross-border divisions are complex processes, and the optimal solution for their promotion is to respect the legality in each and one of the moments of the process and regarding all the legal aspects.

\section{Bibliography}

Cărpenaru, St. D., Predoiu, C., David, S., Piperea, Gh., Legea societăţilor comerciale Comentariu pe articole, Editia 4, Ed. C.h. Beck, Bucureşti, 2009;

Simona Petrina Gavrilă, Legea societăților comerciale, practica judiciară, Hamangiu Publishing House, 2009;

Inalta Curte de Casatie si Jusititie, Buletinul jurisprudentei. Culegere de decizii pe anul 2008, C.H.Beck Publishing House, Bucharest, 2009;

Cornelia Lefter, Societatea cu răspundere limitată în dreptul comparat, "Didactică şi Pedagogică” Publishing House, Bucharest, 1993. 
Law $n^{\circ} .31 / 1990$ on trade companies

Law $n^{\circ}$. 26/1990 regarding the Registry of Commerce.

Directive III $\mathrm{n}^{\circ}$. 78/855/CEE of 9 Oct. 1978 regarding the merger of public limited liability companies.

Directive VI-a $n^{0} .82-891 / E E C$ of 17 Dec. 1982 regarding the division of public limited liability companies. 